\title{
Determination of Beta Radiation Dose to the Thyroid Gland from the Ingestion of ${ }^{131} \mathrm{I}$ by Patients
}

\author{
M. A. Misdaq ${ }^{1, ~ *, ~ H . ~ H a r r a s s ~}{ }^{1}$, M. Karime ${ }^{1}$, A. Matrane M, $^{1,}$ \\ ${ }^{1}$ Nuclear Physics and Techniques Laboratory, Faculty of Sciences Semlalia, University of Cadi Ayyad, Marrakech, Morocco \\ ${ }^{2}$ Nuclear Medicine Service, Mohamed VI University Hospital Centre, Faculty of Medicine and Pharmacy, University of Cadi Ayyad, \\ Marrakech, Morocco
}

Email address:

misdaq@uca.ac.ma (M. A. Misdaq)

${ }^{*}$ Corresponding author

To cite this article:

M. A. Misdaq, H. Harrass, M. Karime, A. Matrane. Determination of Beta Radiation Dose to the Thyroid Gland from the Ingestion of ${ }^{131}$ I by Patients. American Journal of Environmental Protection. Vol. 5, No. 6, 2016, pp. 168-178. doi: 10.11648/j.ajep.20160506.14

Received: May 11, 2016; Accepted: December 12, 2016; Published: January 9, 2017

\begin{abstract}
Total activities due to the ingestion of ${ }^{131} \mathrm{I}$ were evaluated in different compartments of the human body of patients. It has been shown that the ${ }^{131} \mathrm{I}$ activity in urine of patients increases when the ${ }^{131} \mathrm{I}$ uptake decreases which could represent a source of radiation for their relatives when they leave hospitals. A new dosimetric model based on the specific betadose concept was developed for evaluating committed equivalent doses to thyroid due to ${ }^{131}$ I uptake by different age groups of patients. Data obtained are in good agreement with those obtained by using the ICRP model for iodine. Committed equivalent dose to the thyroid gland is influenced by the mass of thyroid, ${ }^{131}$ I uptake and energy of the emitted beta particles. In addition,

${ }^{131}$ I uptake was measured by using a gamma camera and committed equivalent doses to the thyroid gland of female patients from the ingestion of ${ }^{131}$ I for the treatment of hyperthyroidism diseases were evaluated. Data obtained by using our model and the ICRP ingestion dose coefficients are in good agreement with each other.
\end{abstract}

Keywords: ${ }^{131}$ I Uptake, Thyroid Gland, Hyperthyroidism Disease, Beta Dose Assessment

\section{Introduction}

Radioiodine ${ }^{131} \mathrm{I}$ is successfully utilized in nuclear medicine for the treatment of hyperthyroidism and thyroid cancer [1]. This radioisotope emits beta minus particles used for the treatment and gamma photons used for diagnosis. Due to the short range of beta minus particles in tissue, damaging effects of beta radiation is restricted to thyroid cells. Information from the emitted gamma rays are analyzed by a gamma camera coupled to a computer and are transduced in images.

${ }^{131} \mathrm{I}$ is produced in nuclear reactors by bombarding natural tellurium metal $\left({ }^{127} \mathrm{Te}\right)$ by neutrons; it disintegrates by emitting $\beta^{-}$particles with a half-life of 8.04 days to unstable xenon ${ }^{131} \mathrm{Xe}^{*}$ which decays to stable xenon $\left({ }^{131} \mathrm{Xe}\right)$ by emitting gamma photons of different energies and intensities [2]. ${ }^{131} \mathrm{I}$ is widely used for diagnostic [3] and therapeutic [4] purposes. For many decades, radioactive iodine was orally administered to patients for the treatment of benign and malignant thyroid diseases [5-9]. Indeed, a major part of the administered radioiodine will concentrate in the thyroid gland; the emitted $\beta^{-}$particles of short ranges will only damage thyroid cells without any harmful health effects to the neighboring organ tissues. However, the emitted gamma rays may cause radiation damage to other tissues of the patients and other individuals [10]. There are two types of biological effects of ionizing radiation: deterministic and stochastic effects. Deterministic effects are caused by the decrease in or loss of organ function due to cell damage or cell death. In the case of treatment of thyroid cancer or metastases, hyperthyroidism and goiter, the cell killing effect in some or all cells of the thyroid gland or in the metastases is the desired effect. Other organs should not be affected in such a way that deterministic effects will occur. Therefore beta-emitting ${ }^{131} \mathrm{I}$ is often the radionuclide chosen for these treatments, although the associated gamma emission exposes 
also other organs of the patient and other individuals. Stochastic effects are those that result from radiation-induced changes in cells that retain their ability to divide. These modified cells sometimes initiate malignant transformation of a cell, leading to the development of a malignant clone and eventually to a clinically observable cancer.

In the present work activities due ${ }^{131} \mathrm{I}$ were determined in different compartments of the human body of patients following the ingestion of ${ }^{131} \mathrm{I}$. A new dosimetric model based on the formalism of specific beta-dose was developed and beta radiation doses due to the ingestion of ${ }^{131} \mathrm{I}$ by patients for the treatment of hyperthyroidism diseases were determined.

\section{Method of Study}

\subsection{Determination of Activities Due to ${ }^{131}$ I in Different Compartments of the Human Body}

In terms of the International Commission on Radiological Protection (ICRP) biokinetic model for iodine [11] (Figure 1), one can divide the human body into the following compartments:

- The blood (B)

- The thyroid (Th)

- The rest of body $(\mathrm{Rb})$

- The urine (U)

- The faeces $(\mathrm{F})$

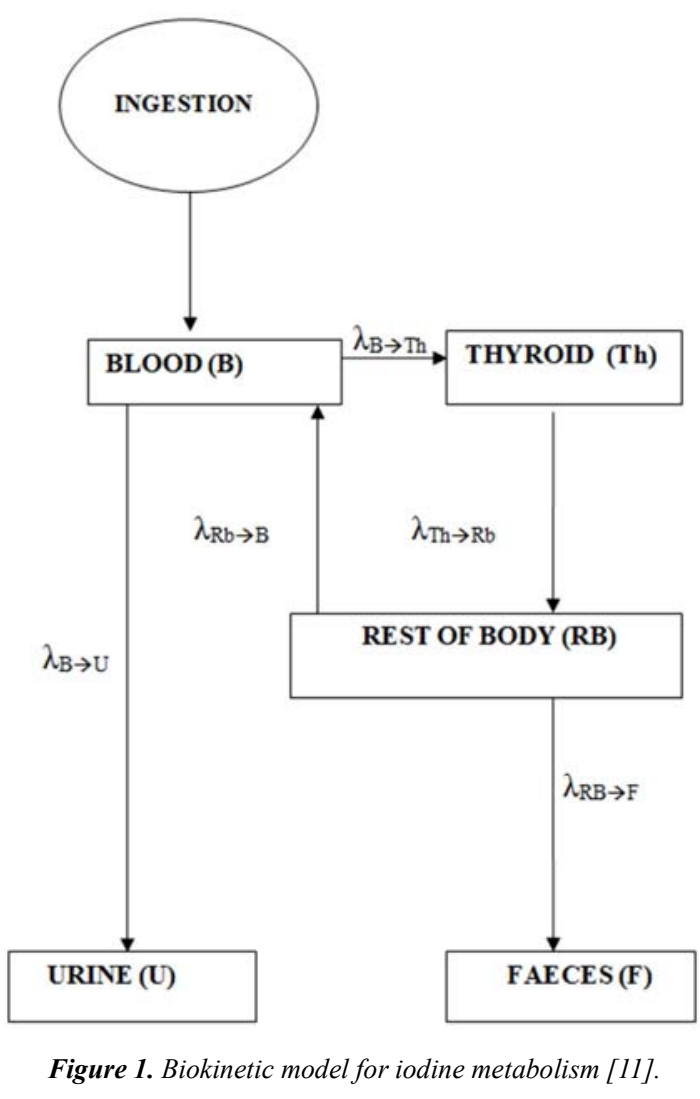

The rates of change of the total activity in the blood, thyroid, rest of body, urine and faeces at any time due to the ingestion of ${ }^{131} \mathrm{I}$ are respectively given by:

$$
\begin{aligned}
& \frac{d A_{C}^{B}\left({ }^{131} I\right)}{d t}=-\left(\lambda_{B \rightarrow T h}+\lambda_{B \rightarrow U}+\lambda_{R}\right) A_{C}^{B}\left({ }^{131} I\right)+\lambda_{R b \rightarrow B} A_{C}^{R b}\left({ }^{131} I\right) \\
& \frac{d A_{\mathcal{C}}^{T h}\left({ }^{131} I\right)}{d t}=-\left(\lambda_{T h} \rightarrow R \mathrm{~b}+\lambda_{R}\right) A_{C}^{T h}\left({ }^{131_{I}}\right)+\lambda_{B \rightarrow T h} A_{C}^{B}\left({ }^{131} I\right) \\
& \frac{d A_{\mathcal{C}}^{R b}\left({ }^{131} I\right)}{d t}=-\left(\lambda_{R \mathrm{~b} \rightarrow B}+\lambda_{R \mathrm{~b} \rightarrow F}+\lambda_{R}\right) A_{\mathcal{C}}^{R b}\left({ }^{131} I\right)+\lambda_{T \mathrm{~h} \rightarrow R \mathrm{~b}} A_{\mathcal{C}}^{T h}\left({ }^{131} I\right) \\
& \frac{d A_{\mathcal{C}}^{U}\left({ }^{131} I\right)}{d t}=\lambda_{B \rightarrow U} A_{\mathcal{C}}^{B}\left({ }^{131} I\right)-\lambda_{R} A_{\mathcal{C}}^{U}\left({ }^{131} I\right)
\end{aligned}
$$

and

$$
\frac{d A_{\mathcal{C}}^{F}\left({ }^{131} I\right)}{d t}=\lambda_{R \mathrm{~b} \rightarrow F} A_{\mathcal{C}}^{R b}\left({ }^{131} I\right)-\lambda_{R} A_{\mathcal{C}}^{F}\left({ }^{131} I\right)
$$

where:

$A_{C}^{B}\left({ }^{131} I\right)(\mathrm{Bq})$ is the total activity at time t due to ${ }^{131} \mathrm{I}$ in blood. $A_{\mathcal{C}}^{T h}\left({ }^{131} I\right)(\mathrm{Bq})$ is the total activity due to ${ }^{131} \mathrm{I}$ in the thyroid. $A_{\mathcal{C}}^{R b}\left({ }^{131} I\right)$ is the total activity at time t due to ${ }^{131} \mathrm{I}$ in the rest of body. $A_{C}^{U}\left({ }^{131} I\right)$ is the total activity at time $\mathrm{t}$ due to ${ }^{131} \mathrm{I}$ in the urine. $A_{\mathcal{C}}^{F}\left({ }^{131} I\right)$ is the total activity at time t due to ${ }^{131} \mathrm{I}$ in the faeces. $\lambda_{R}$ is the decay constant of the ${ }^{131} \mathrm{I}$ radionuclide. $\lambda_{B \rightarrow T h}\left(\mathrm{~d}^{-1}\right)$ is the transfer rate $\left(\mathrm{d}^{-1}\right)$ for ${ }^{131} \mathrm{I}$ from blood to thyroid. $\lambda_{B \rightarrow U}\left(\mathrm{~d}^{-1}\right)\left(\mathrm{d}^{-1}\right)$ is the transfer rate for ${ }^{131} \mathrm{I}$ from blood to urine. $\lambda_{B \rightarrow T h}\left(\mathrm{~d}^{-1}\right)={ }^{131} \mathrm{I}$ uptake $\mathrm{x}$ $\mathrm{Ln} 2 / \mathrm{T}_{\mathrm{B}}$ and $\lambda_{B \rightarrow U}\left(\mathrm{~d}^{-1}\right)=\left(1-{ }^{131}\right.$ I uptake) $\mathrm{x}$ Ln2/T $\mathrm{B}$ (Table 1(a)) [1]. $\mathrm{T}_{\mathrm{B}}=0.25 \mathrm{~d}$ is the biological half-time of blood. $\lambda_{T \mathrm{~h} \rightarrow R \mathrm{~b}}\left(\mathrm{~d}^{-1}\right)$ is the transfer rate for ${ }^{131} \mathrm{I}$ from thyroid to the rest of body. $\lambda_{R \mathrm{~b} \rightarrow B}\left(\mathrm{~d}^{-1}\right)$ is the transfer rate for ${ }^{131} \mathrm{I}$ from the rest of body to blood. $\lambda_{R \mathrm{~b} \rightarrow F}\left(\mathrm{~d}^{-1}\right)$ is the transfer rate 
for ${ }^{131} \mathrm{I}$ from the rest of body to faeces. $\lambda_{T h} \rightarrow R \mathrm{~b}\left(\mathrm{~d}^{-1}\right)$, $\lambda_{R \mathrm{~b} \rightarrow B}\left(\mathrm{~d}^{-1}\right)$ and $\lambda_{R \mathrm{~b} \rightarrow F}\left(\mathrm{~d}^{-1}\right)$ depend on the age group of patients (Table 1(b)) [1].

Table 1. Transfer rates of ${ }^{131}$ I for (a) different age groups of patients and (b) different ${ }^{131}$ I uptakes [1].

Table 1. (a).

\begin{tabular}{|c|c|c|c|c|c|}
\hline \multicolumn{6}{|c|}{ Age group of patients. } \\
\hline $\begin{array}{l}\text { Transfert } \\
\text { rate (d-1) }\end{array}$ & 1 year & 5 years & 10 years & 15 years & Adult \\
\hline$\lambda_{\mathrm{Th} \rightarrow \mathrm{Rb}}$ & 0.0231 & 0.0173 & 0.0137 & 0.0107 & 0.0087 \\
\hline$\lambda_{\mathrm{Rb} \rightarrow \mathrm{Bl}}$ & 0.0924 & 0.0603 & 0.0239 & 0.0207 & 0.0115 \\
\hline$\lambda_{\mathrm{Rb} \rightarrow \mathrm{F}}$ & 0.3697 & 0.2411 & 0.0956 & 0.0828 & 0.0462 \\
\hline
\end{tabular}

Table 1. (b).

\begin{tabular}{cllllll}
\hline \multicolumn{2}{l|}{${ }^{131}$ I uptake (\%). } & & & & & \\
\hline $\begin{array}{c}\text { Transfert } \\
\text { rate }\left(\mathbf{d}^{-1}\right)\end{array}$ & $\mathbf{5}$ & $\mathbf{1 5}$ & $\mathbf{2 5}$ & $\mathbf{3 5}$ & $\mathbf{4 5}$ & $\mathbf{5 5}$ \\
\hline$\lambda_{\mathrm{Bl} \rightarrow \mathrm{Th}}$ & 0.1386 & 0.4159 & 0.6931 & 0.9704 & 1.2477 & 1.5249 \\
$\lambda_{\mathrm{Bl} \rightarrow \mathrm{Ur}}$ & 2.6340 & 2.3567 & 2.0794 & 1.8022 & 1.5249 & 1.2477 \\
\hline
\end{tabular}

Total activities due to ${ }^{131} \mathrm{I}$ in the different compartments of the human body are obtained by solving the last differential equation system (Equations (1)-(5)) by using a Maple 8 code [12] providing that at $\mathrm{t}=0$ these activities are equal to zero except that in the blood which is equal to $A_{c}(0)$. Indeed, for an $n^{\text {th }}$ compartment one has:

$$
A_{C}^{n}\left({ }^{131} I\right)(t)=A_{c}(0) \sum_{l=1}^{3} a_{l}^{n} e^{-\gamma_{l}^{n} t}
$$

where $\mathrm{A}_{\mathrm{c}}(0)=1 \mathrm{~Bq}$ is the ${ }^{131} \mathrm{I}$ intake at time $\mathrm{t}=0, a_{l}^{n}$ is a constant and $\gamma_{l}^{n}$ is a rate constant in $\mathrm{d}^{-1}$.

\subsection{A New Dosimetric Model for Evaluating Beta-Committed Equivalent Dose Due to ${ }^{131}$ I in the Thyroid Gland of Patients}

Beta-equivalent dose rate $\left(\mathrm{Sv} \mathrm{s}^{-1}\right)$ due to ${ }^{131} \mathrm{I}$ in the thyroid (Th) of a patient is given by:

$$
\dot{\mathrm{H}} \mathrm{Th}\left({ }^{131} \mathrm{I}\right)(\mathrm{t})=\mathrm{A}_{\mathrm{C}}^{\mathrm{Th}}\left({ }^{131} \mathrm{I}\right)(\mathrm{t}) \mathrm{D}_{\mathrm{Sp}}^{\mathrm{Th}}\left({ }^{131} \mathrm{I}\right) \mathrm{W}_{\mathrm{R}}
$$

Where: $A_{C}^{T h}\left({ }^{131} I\right)(\mathrm{t})(\mathrm{Bq})$ is the total activity due to ${ }^{131} \mathrm{I}$ at time $\mathrm{t}$ in the thyroid. $D_{S p}^{T h}\left({ }^{131} \mathrm{I}\right)$ is the specific beta-dose (Gy) deposited by $\beta^{-}$particles emitted by $1 \mathrm{~Bq}$ of ${ }^{131} \mathrm{I}$ in the thyroid tissue. $W_{R}$ is the radiation weighting factor which is equal to unity for beta- particles [13].

The $D_{S p}^{T h}\left({ }^{131} I\right)$ specific beta-dose is given by:

$$
D_{\mathrm{Sp}}^{\mathrm{Th}}\left({ }^{131} \mathrm{I}\right)=\mathrm{k} \sum_{\mathrm{j}} \frac{\mathrm{K}_{\mathrm{j}} \mathrm{R}_{\mathrm{j}} \mathrm{S}_{\mathrm{j}}}{\mathrm{M}_{\mathrm{Th}}}
$$

Where: $K_{j}$ is the emission percentage of a beta minus particle of index $j$ and average energy $E_{\beta}$ emitted by ${ }^{131} I$ [2]. $R_{j}(\mathrm{~cm})$ is the range of a beta minus particle of index $j$ and average energy $E_{\beta}$ emitted by ${ }^{131} \mathrm{I}$ in the thyroid tissue. $\mathrm{k}=1.6 \times 10^{-13} \mathrm{~J} \mathrm{MeV}^{-1}$ is a conversion factor. $\mathrm{S}_{\mathrm{j}}\left(\mathrm{MeVcm}^{-1}\right)$ is the stopping power of the thyroid tissue for a beta minus particle of index $j$ and average energy $E_{\beta}$ emitted by ${ }^{131} I . R_{j}$ and $S_{j}$ were determined by using an ESTAR code [14] and the chemical composition of thyroid given by in the ICRP Publication 89 [15] (Table 2). $\mathrm{M}_{\mathrm{Th}}$ is the mass (g) of the thyroid (Table 3) [15].

Table 2. Values of the ranges of $\beta$ particles emitted by ${ }^{131} I$ in thyroid and stopping powers of the thyroid for the emitted $\beta$ particles [2].

\begin{tabular}{llll}
\hline $\mathbf{E}_{\boldsymbol{\beta}}^{-}$(average) & Emission pourcentage & $\mathbf{R j}$ & $\mathbf{S}_{\mathbf{j}}$ \\
\hline$(\mathrm{MeV})$ & $(\%)$ & $\left(10^{-3} \mathrm{~cm}\right)$ & $(\mathrm{MeV} / \mathrm{cm})$ \\
0.069 & 2.1 & 9.63 & 6.534 \\
0.097 & 7.4 & 17.36 & 5.175 \\
0.192 & 89.4 & 57.04 & 3.520 \\
0.869 & 0.6 & 476.80 & 2.316 \\
\hline
\end{tabular}

Table 3. Mass of thyroid for different age groups of patients [15].

\begin{tabular}{ll}
\hline Age group of patients & Mass of thyroid (g) \\
\hline 1 year & 1.8 \\
5 years & 3.4 \\
10 years & 7.9 \\
15 years & 12 \\
Adult female & 17 \\
Adult male & 20 \\
\hline
\end{tabular}

The beta- committed equivalent dose (Sv) due to ${ }^{131} \mathrm{I}$ in the thyroid gland is given by:

$$
\mathrm{H}_{\mathrm{Th}}\left({ }^{\left.131_{\mathrm{I}}\right)}=\int_{0}^{\tau} \dot{\mathrm{H}}_{\mathrm{Th}}\left({ }^{131} \mathrm{I}\right)(\mathrm{t}) \mathrm{dt}\right.
$$

where $\tau$ is the exposure time which is equal to 50 years for adults and to 70 years for children.

This committed equivalent dose could also be evaluated by using the following relationship:

$$
\mathrm{H}_{\mathrm{Th}}\left({ }^{131} \mathrm{I}\right)=\mathrm{A}_{\mathrm{c}}(0) \mathrm{h}_{\mathrm{Th}}\left({ }^{131} \mathrm{I}\right)
$$

where $\mathrm{h}_{\mathrm{Th}}\left({ }^{131} \mathrm{I}\right)$ is the ingestion dose coefficient for ${ }^{131} \mathrm{I}$ $\left(\mathrm{SvBq}^{-1}\right)$ for a given ${ }^{131}$ I uptake [1].

\section{Results and Discussion}

\subsection{Total Activities Determined in Different Compartments of the Human Body of Patients from the Ingestion of ${ }^{131} \mathrm{I}$}

Activities due to ${ }^{131} \mathrm{I}$ were determined in different compartments of the human body of patients from the ingestion of ${ }^{131} \mathrm{I}$ by using Equation (6). Variation of the ${ }^{131} \mathrm{I}$ activity in blood, thyroid, rest of body and urine as functions of time are shown in figures (2)-(5) for adults, and 1year children patients for different ${ }^{131} \mathrm{I}$ uptakes, respectively. It is 
to be noted that the residence time of ${ }^{131} \mathrm{I}$ in the thyroid and rest of body (Figures 2(b) and 2(c)) is higher than that in blood (Figure 2(a)). This is because the transfer rates of ${ }^{131} \mathrm{I}$ from thyroid to the rest of body $\left(\lambda_{T h} \rightarrow R \mathrm{~b}\right)$ and from the rest of body to faeces $\left(\lambda_{R b \rightarrow F}\right)$ are lower than that from blood to urine ( $\lambda_{B \rightarrow U}$ ) (Table 1). The retention function for ${ }^{131} \mathrm{I}$ in thyroid is higher for adult (Figures 2(b) and 3(b)) than for 1year children patients (Figures 4 (b) and 5 (b)), respectively. This is due to the fact that the transfer rate of
${ }^{131}$ I from the thyroid to the rest of body is higher for 1year children than for adults (Table 1). One can note that when the ${ }^{131}$ I uptake increases (from $5 \%$ to $55 \%$, for instance) for adults (Figures 2 and 3) and 1year children (Figures 4 and 5) the ${ }^{131}$ I activity in urine decreases. This is because $\lambda_{B \rightarrow U}$ decreases when the ${ }^{131}$ I uptake increases (Table 1 (b)). The presence of ${ }^{131} \mathrm{I}$ in urine of patients after lower ${ }^{131} \mathrm{I}$ uptake treatment could represent a source of radiation for their relatives when using common family toilets.

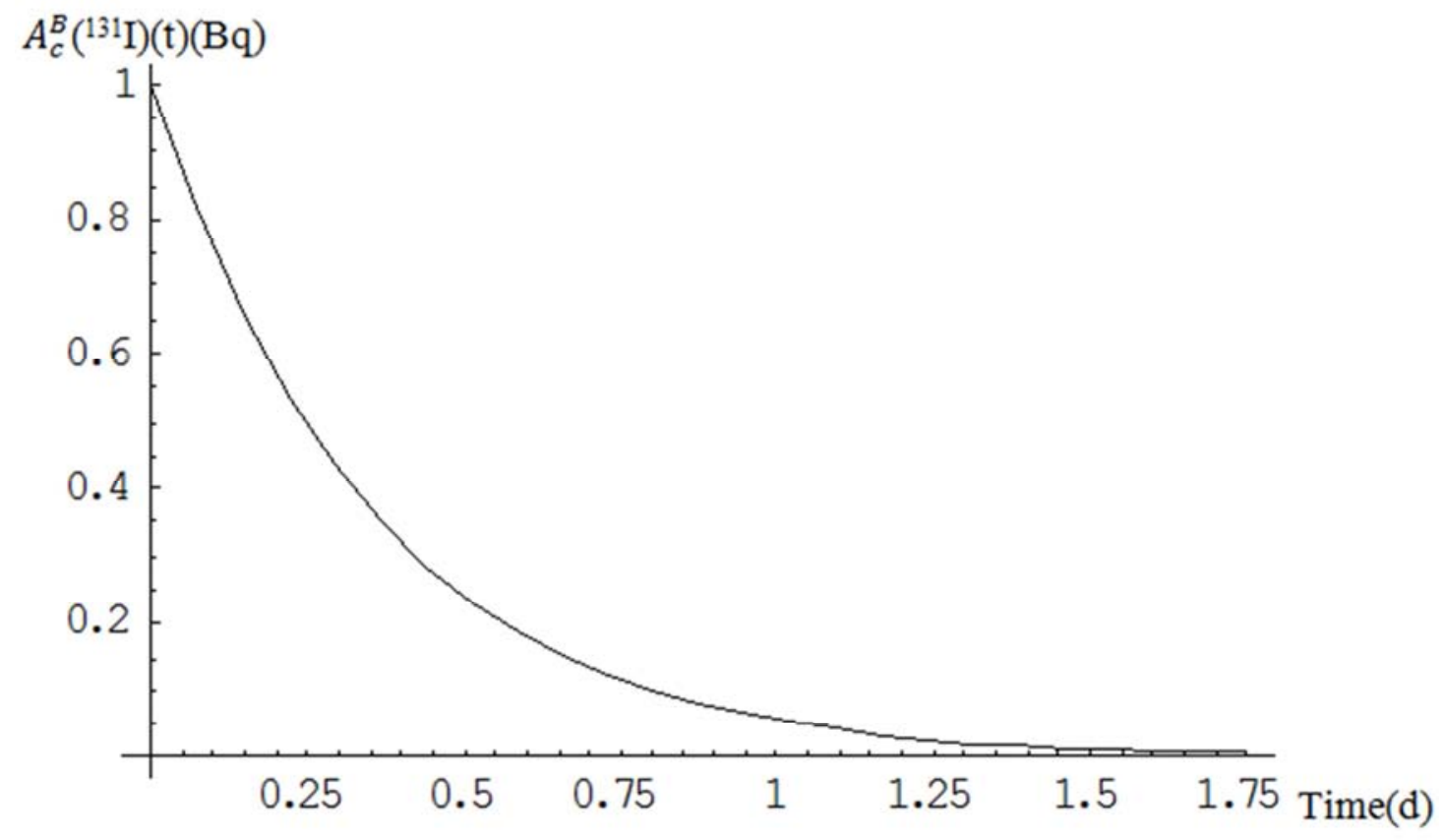

(a)

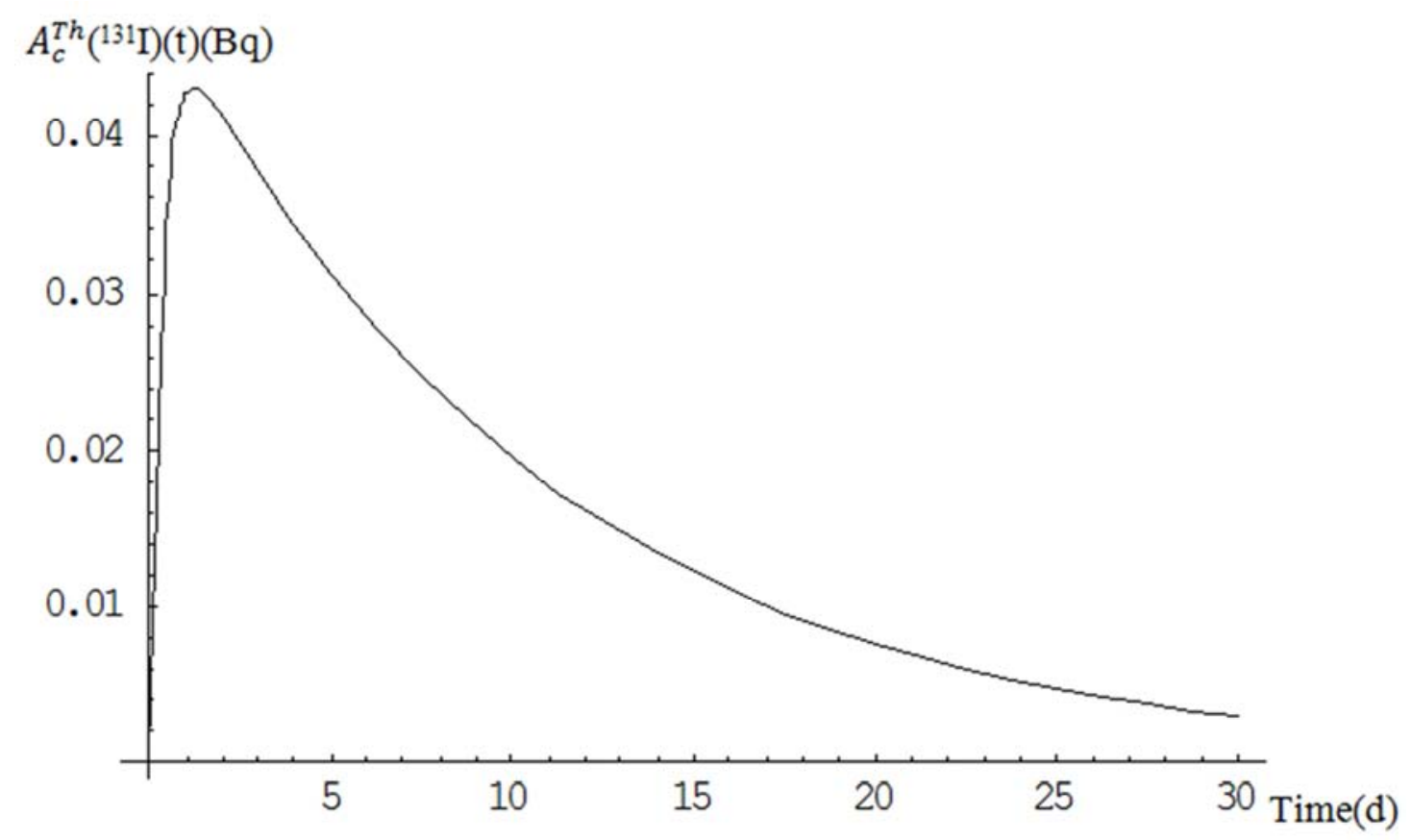

(b) 


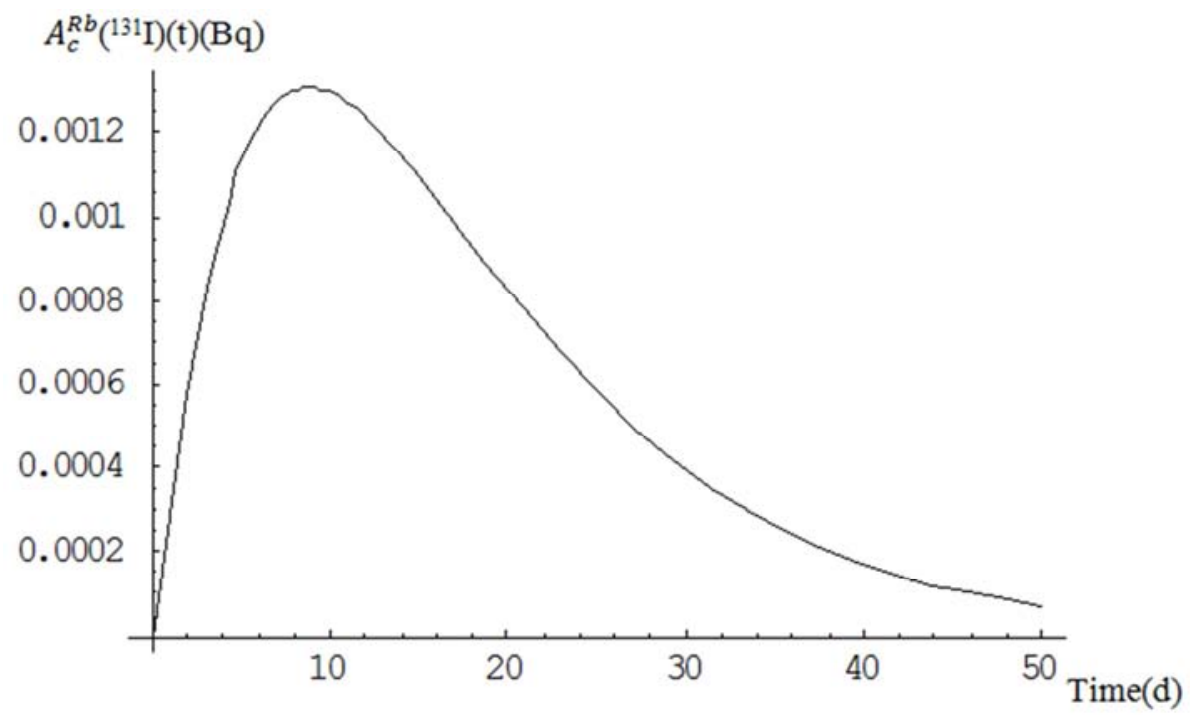

(c)

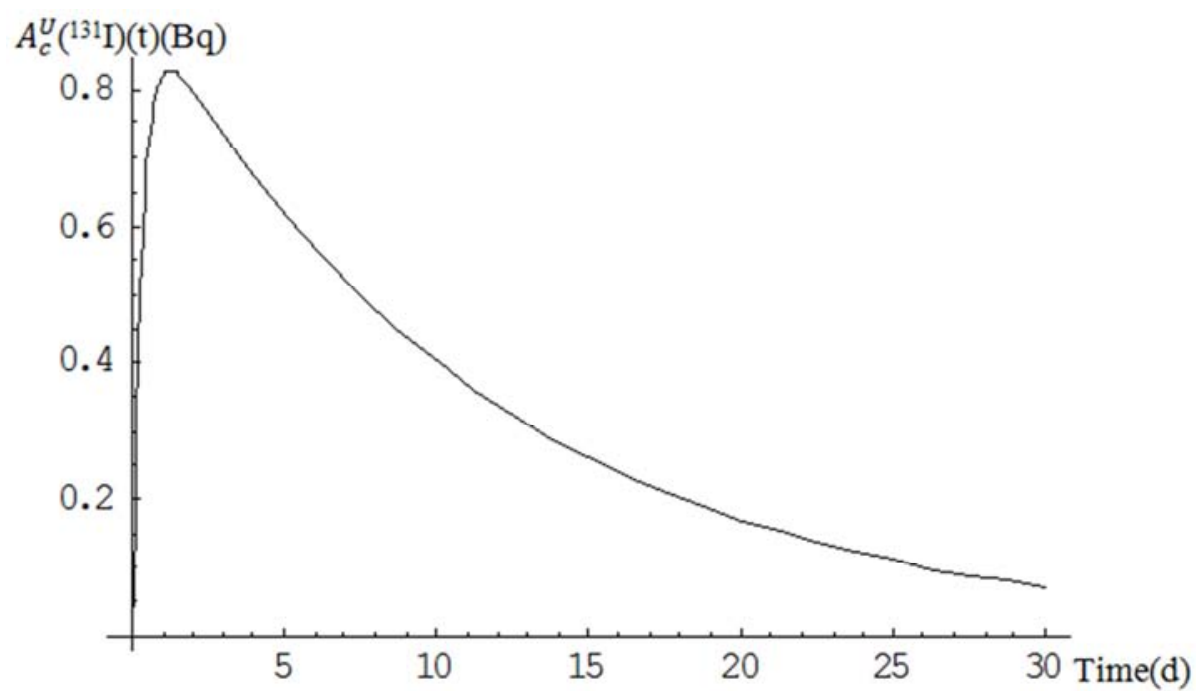

(d)

Figure 2. Variation of the ${ }^{131}$ I activity as a function of time in blood (a), thyroid (b), rest of body (c), and urine (d) for adult patients. The ${ }^{131}$ I uptake is of $5 \%$.

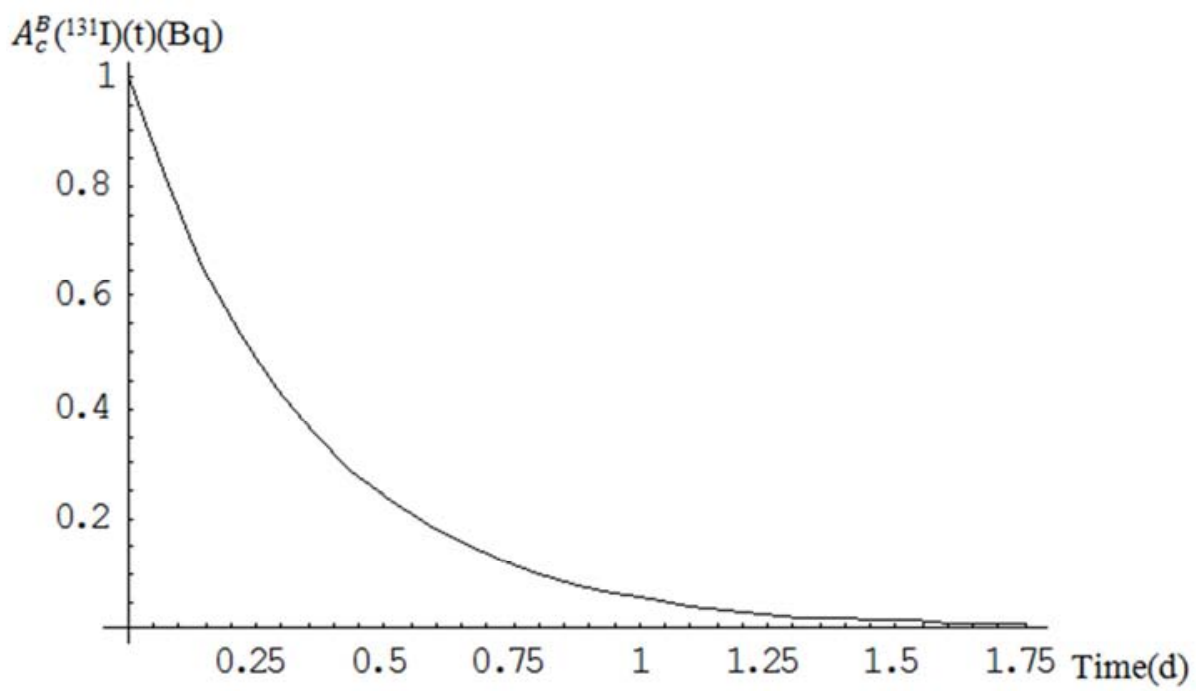

(a) 


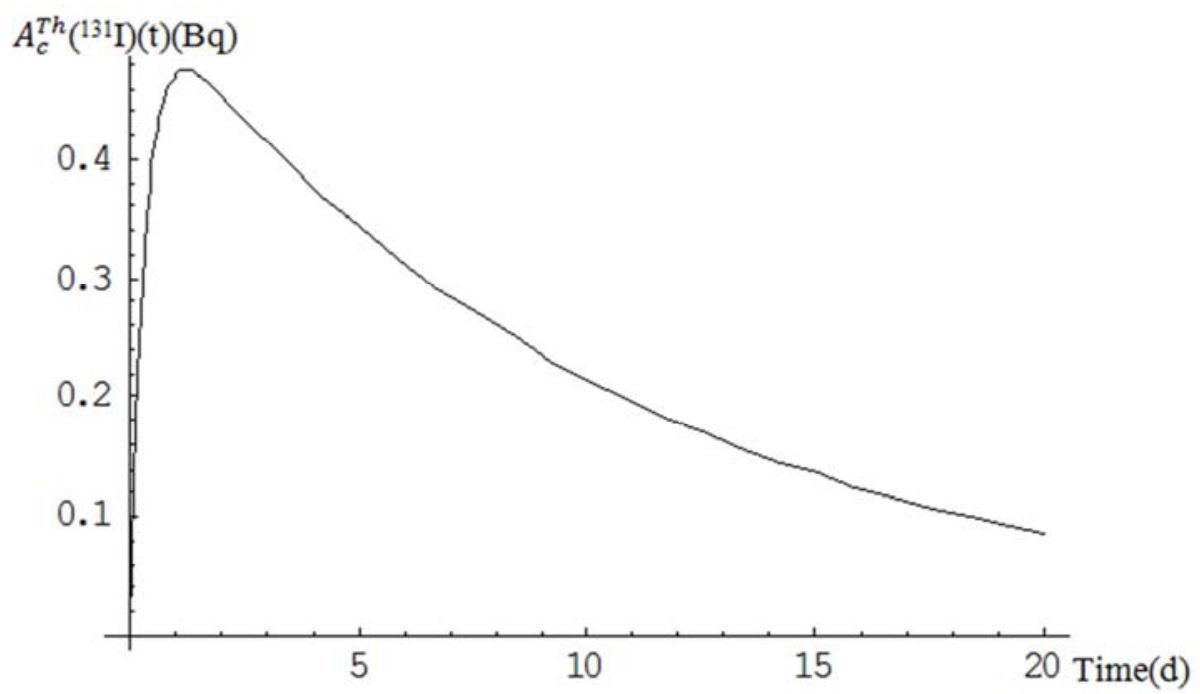

(b)

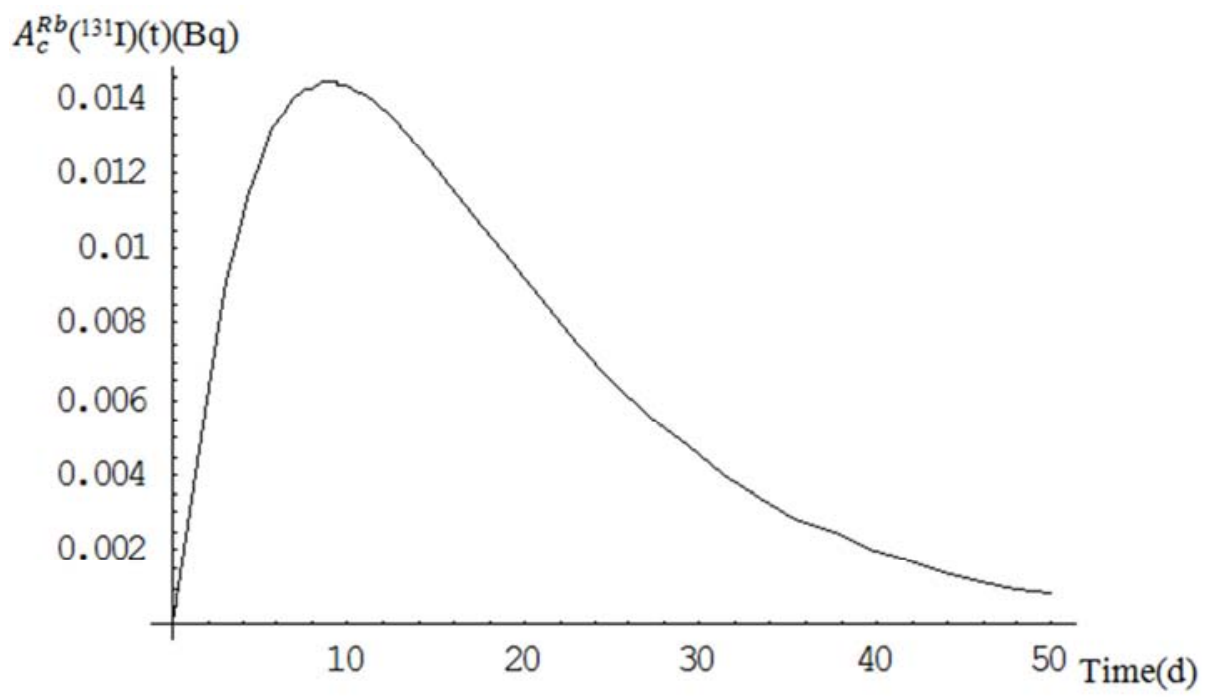

(c)

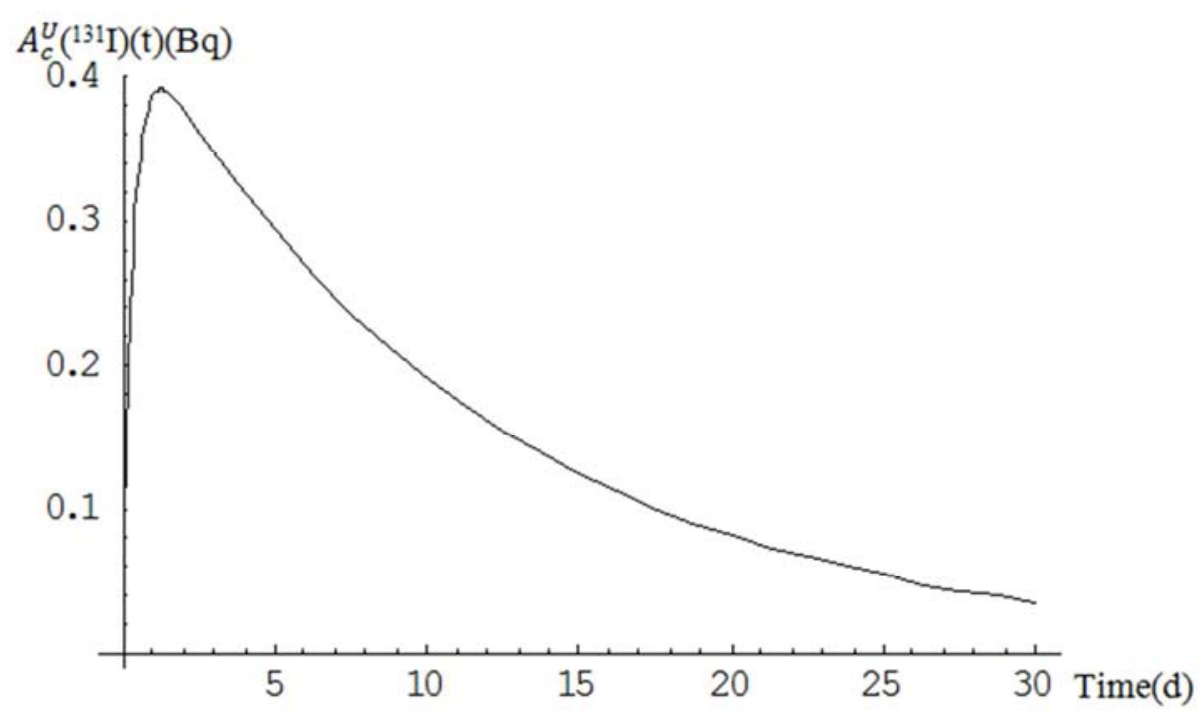

(d)

Figure 3. Variation of the ${ }^{131}$ I activity as a function of time in blood (a), thyroid (b), rest of body (c), and urine (d) for adult patients. The ${ }^{131}$ I uptake is of $55 \%$. 


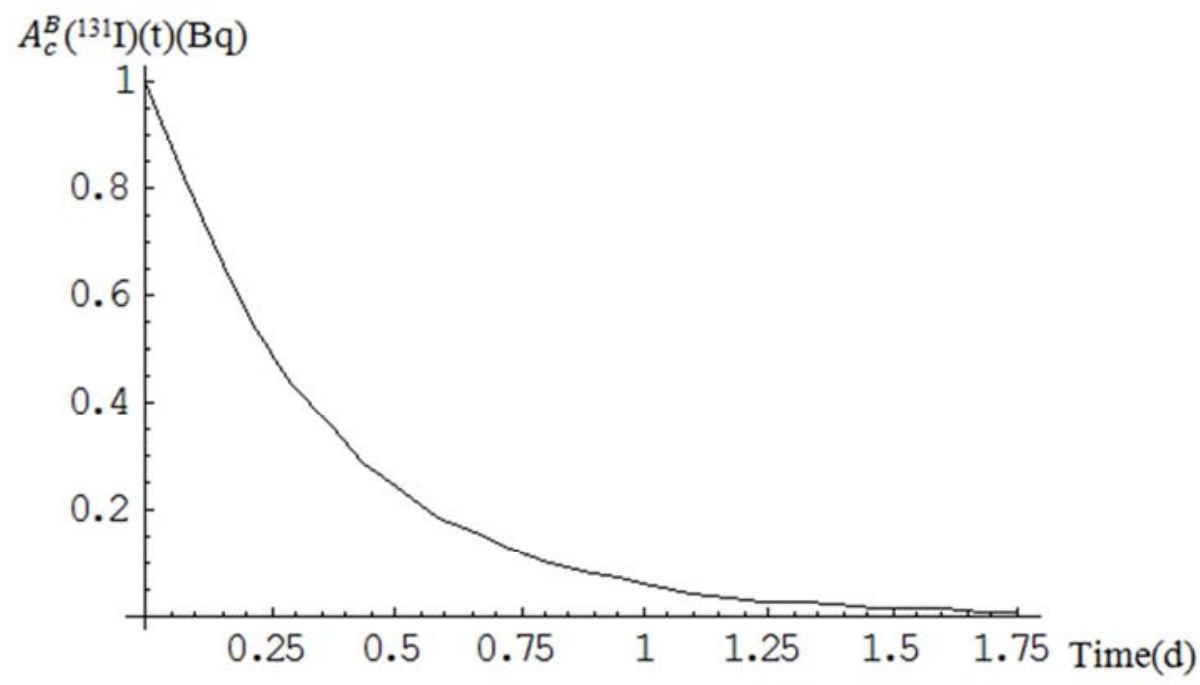

(a)

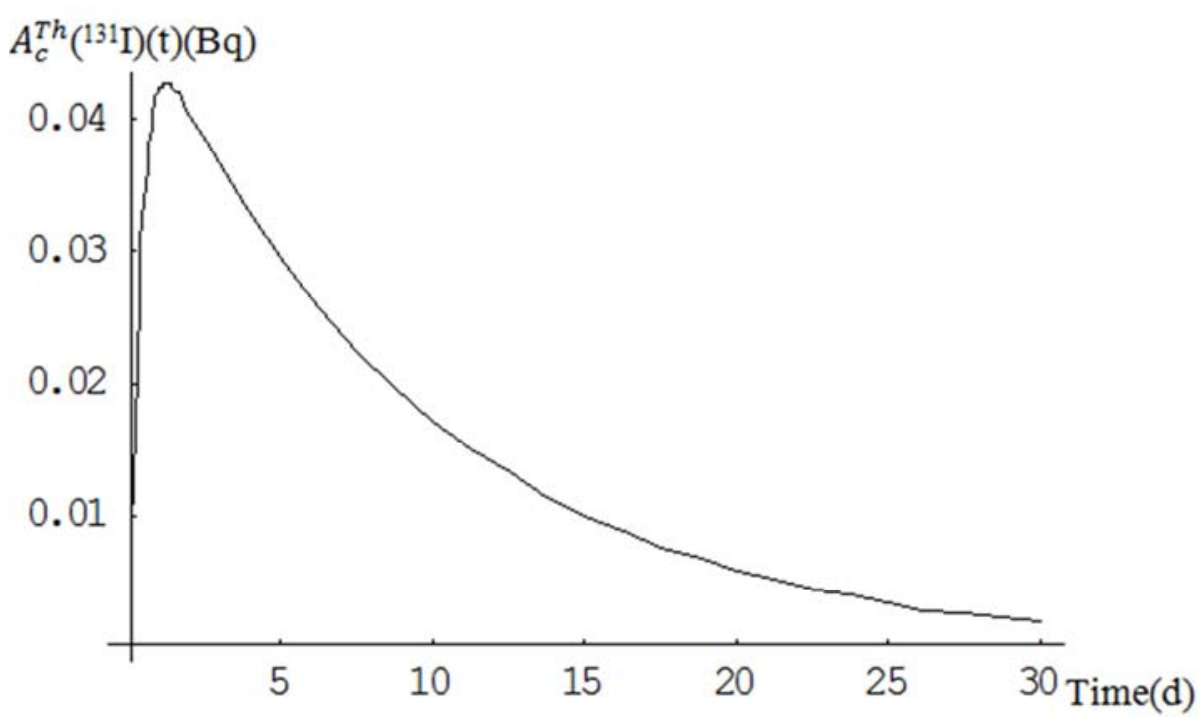

(b)

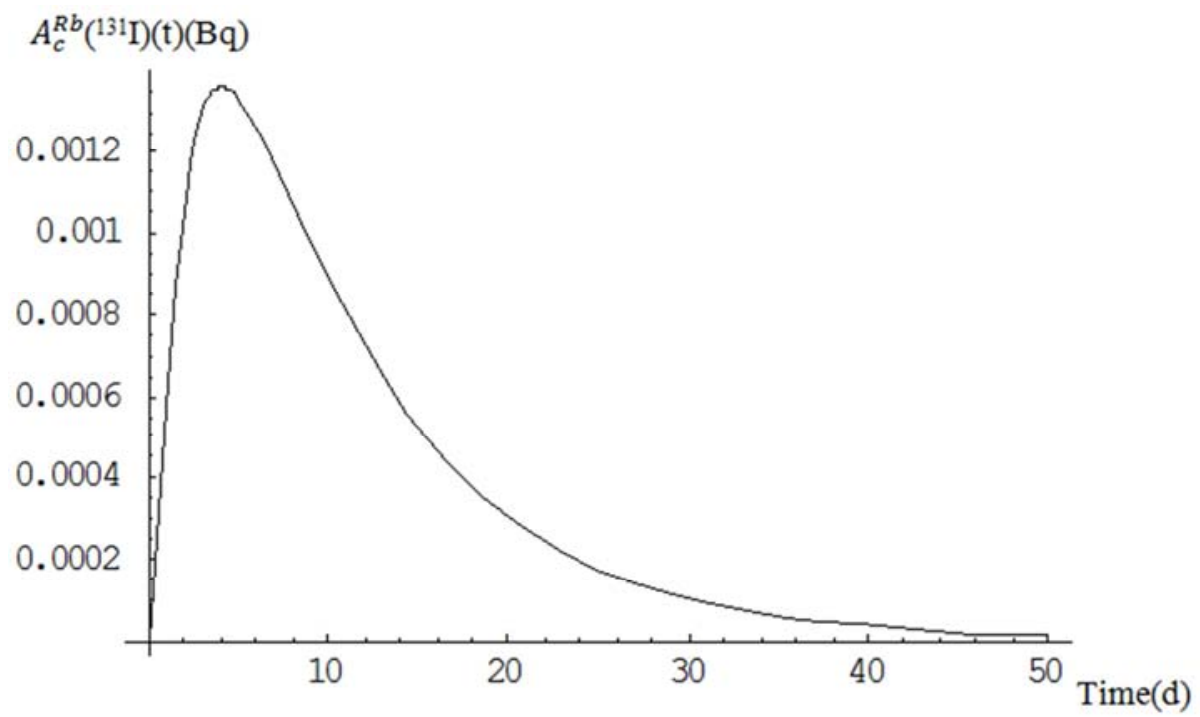

(c) 


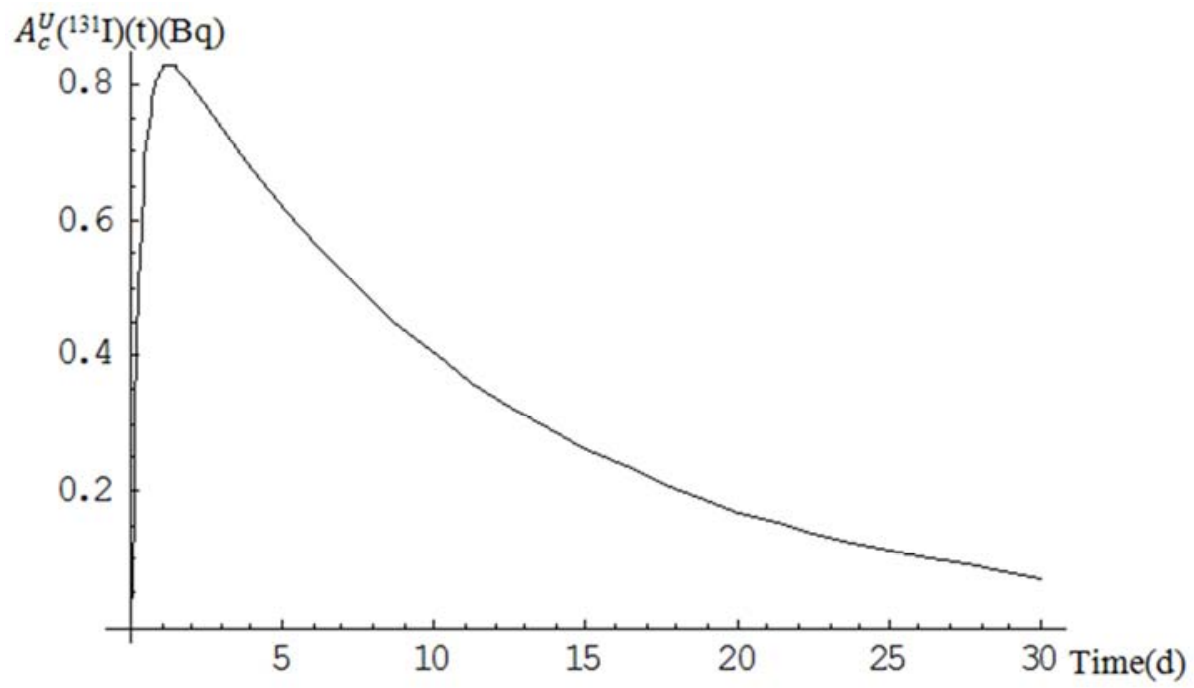

(d)

Figure 4. Variation of the ${ }^{131}$ I activity as a function of time in blood (a), thyroid (b), rest of body (c), and urine (d) for lyear children patients. The ${ }^{131}$ I uptake is of $5 \%$.

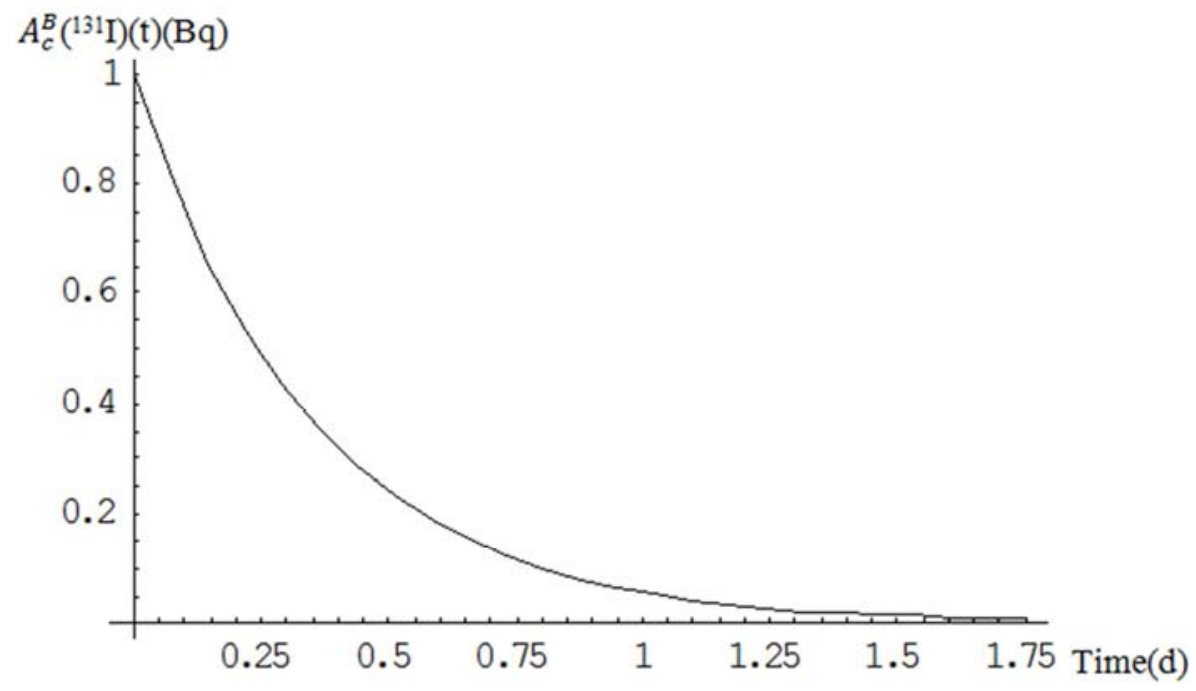

(a)

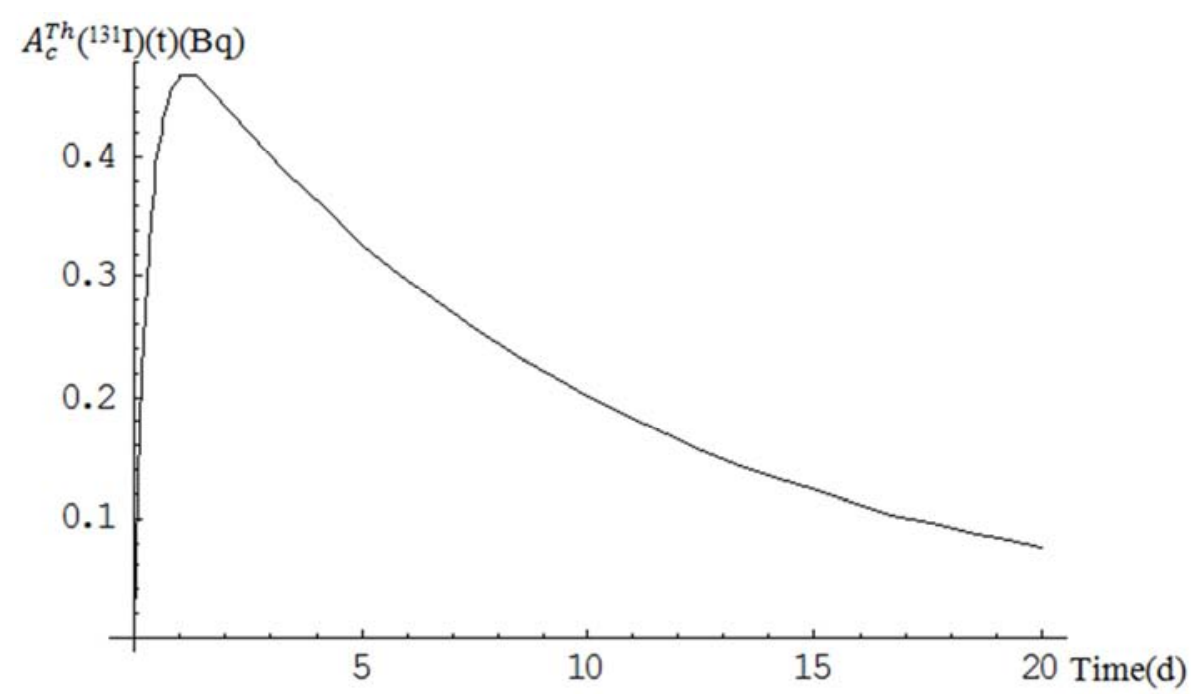

(b) 


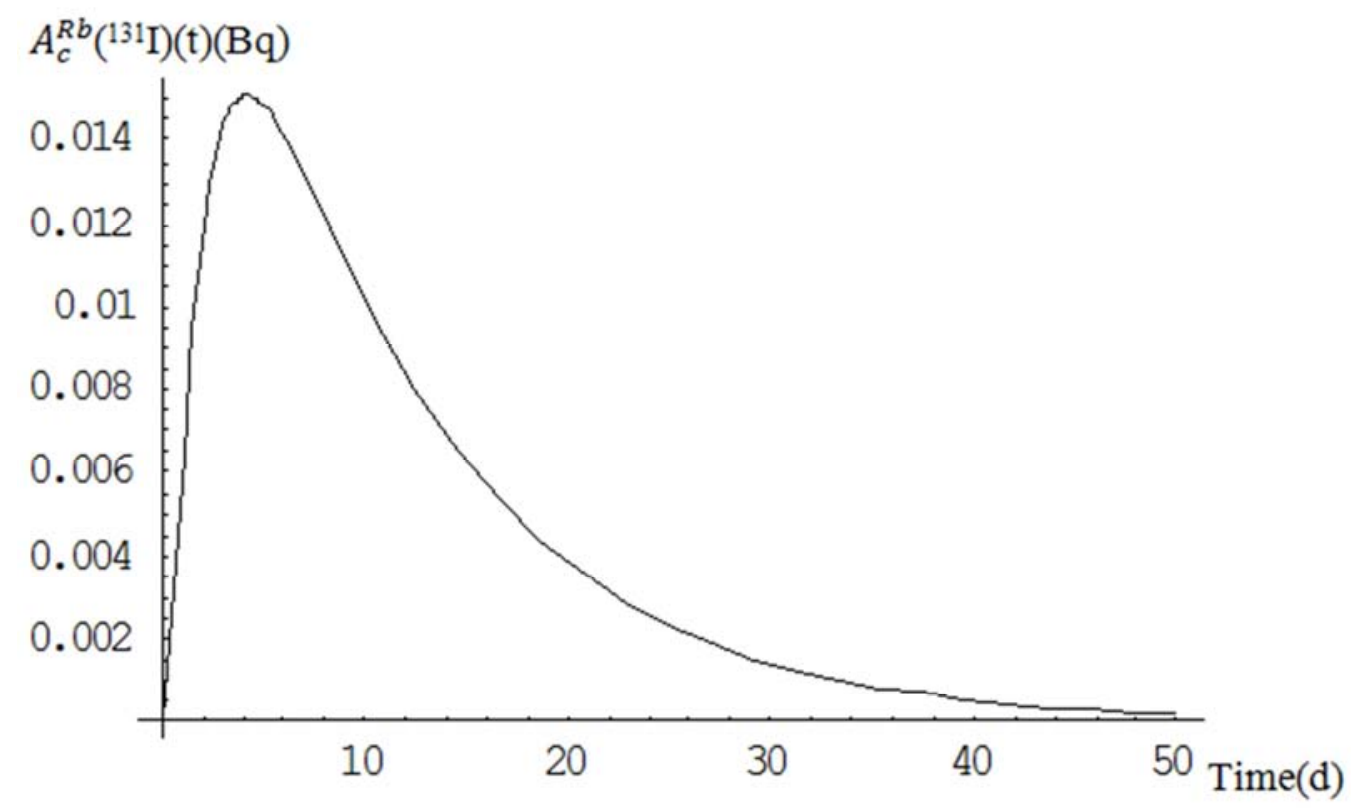

(c)

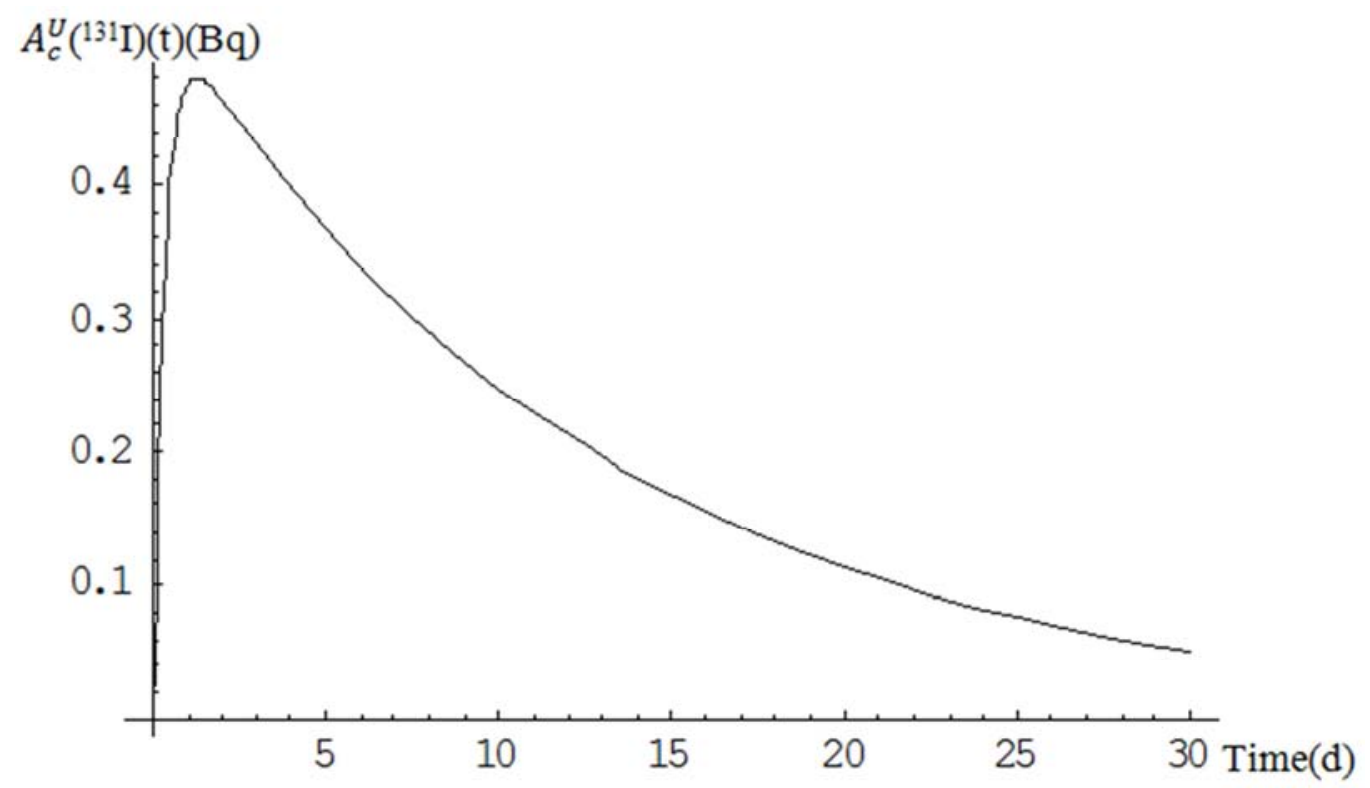

(d)

Figure 5. Variation of the ${ }^{131}$ I activity as a function of time in blood (a), thyroid (b), rest of body (c), and urine (d) for Iyear children patients. The ${ }^{131}$ I uptake is of $55 \%$.

\subsection{Beta Committed Equivalent Dose to Thyroid Due to the Ingestion of ${ }^{131}$ I by Patients}

In order to test the validity of our dosimetric model committed equivalent doses per unit intake $\left(\mathrm{h}_{\mathrm{Th}}\left({ }^{131} \mathrm{I}\right)\right)$ were determined in the thyroid of various age groups of patients from the ingestion of ${ }^{131} \mathrm{I}$ by using Equation (9). Data obtained are shown in Table 4. Considering uncertainties on ranges and stopping powers [14], the relative uncertainty of the committed equivalent dose is estimated to be about $10 \%$. Data obtained are in good agreement with those obtained by using the ICRP model [1]. $\mathrm{h}_{\mathrm{Th}}\left({ }^{131} \mathrm{I}\right)$ is influenced by the thyroid mass and activity integral (Eq. (9)). It is to be noted from results shown in Table 4 that committed equivalent dose per unit intake to thyroid is clearly higher for children than for adults, for a given ${ }^{131}$ I uptake. This is because the thyroid mass is predominant (Equation (9)). Indeed, the ratio of the corresponding highest committed equivalent doses $\left[\mathrm{h}_{\mathrm{Th}}\right.$ $(1 \mathrm{y}) / \mathrm{h}_{\mathrm{Th}}$ (Adult)] is equal to 10.29 and the ratio of the corresponding thyroid masses $\left[\mathrm{M}_{\mathrm{Th}}{ }^{-1}(1 \mathrm{y}) / \mathrm{M}_{\mathrm{Th}}{ }^{-1}\right.$ (Adult) $]$ (Equation (9)) is equal to 11.11 (Table 3), whereas the ratio of the corresponding ${ }^{131} \mathrm{I}$ activity integral is equal to 0.93 for an ${ }^{131}$ I uptake of $55 \%$. One can also note that for a given age group of patients, committed equivalent dose per unit intake to thyroid increases with the ${ }^{131}$ I uptake. 
Table 4. Data obtained for the ingestion dose coefficient for ${ }^{131} I$ in thyroid $\left(h_{T h}\left({ }^{131} I\right)\right)$ for different age groups of patients and different ${ }^{131}$ I uptakes: $5 \%$ (a), 15\% (b), 25\% (c), 35\% (d), 45\% (e) and 55\% (f), by using this method and the ICRP ingestion dose coefficient [1].

\section{Table 4. (a)}

\begin{tabular}{lll}
\hline & \multicolumn{2}{l}{ Dose coefficient in thyroid $\mathbf{h}_{\mathrm{Th}}\left({ }^{\mathbf{1 3 1}} \mathbf{I}\right)(\boldsymbol{\mu G} / \mathbf{B q})$} \\
\hline Patient age group & This method & $\mathbf{I C R P}$ ose coefficient \\
\hline 1 year & $0.66 \pm 0.07$ & 0.68 \\
5 years & $0.36 \pm 0.04$ & 0.37 \\
10 years & $0.16 \pm 0.02$ & 0.17 \\
15 years & $0.11 \pm 0.01$ & 0.11 \\
Adult female & $0.08 \pm 0.01$ & - \\
Adult male & $0.06 \pm 0.01$ & 0.07 \\
\hline
\end{tabular}

Table 4. (b).

\begin{tabular}{lll}
\hline & \multicolumn{2}{l}{ Dose coefficient in thyroid $\mathbf{h}_{\mathbf{T h}}\left({ }^{131} \mathbf{I}\right)(\boldsymbol{\mu G} \mathbf{G} / \mathbf{B q})$} \\
\hline Patient age group & This method & ICRP dose coefficient \\
\hline 1 year & $2.0 \pm 0.2$ & 2.00 \\
5 years & $1.1 \pm 0.1$ & 1.10 \\
10 years & $0.50 \pm 0.05$ & 0.51 \\
15 years & $0.34 \pm 0.03$ & 0.34 \\
Adult female & $0.24 \pm 0.02$ & - \\
Adult male & $0.20 \pm 0.02$ & 0.21 \\
\hline
\end{tabular}

Table 4. (c).

\begin{tabular}{lll}
\hline & \multicolumn{2}{l}{ Dose coefficient in thyroid $\mathbf{h}_{\mathrm{Th}}\left({ }^{131} \mathbf{I}\right)(\boldsymbol{\mu G} / \mathbf{B q})$} \\
\hline Patient age group & This method & ICRP dose coefficient \\
\hline 1 year & $3.4 \pm 0.3$ & 3.40 \\
5 years & $1.8 \pm 0.1$ & 1.90 \\
10 years & $0.83 \pm 0.08$ & 0.84 \\
15 years & $0.56 \pm 0.06$ & 0.56 \\
Adult female & $0.40 \pm 0.04$ & - \\
Adult male & $0.34 \pm 0.03$ & 0.36 \\
\hline
\end{tabular}

Table 4. (d).

\begin{tabular}{|c|c|c|}
\hline \multirow[b]{2}{*}{ Patient age group } & \multicolumn{2}{|c|}{ Dose coefficient in thyroid $h_{T h}\left({ }^{131} I\right)(\mu G y / B q)$} \\
\hline & This method & ICRP dose coefficient \\
\hline 1 year & $4.8 \pm 0.4$ & 4.70 \\
\hline 5 years & $2.6 \pm 0.2$ & 2.60 \\
\hline 10 years & $1.2 \pm 0.1$ & 1.20 \\
\hline 15 years & $0.79 \pm 0.08$ & 0.79 \\
\hline Adult female & $0.57 \pm 0.06$ & - \\
\hline Adult male & $0.48 \pm 0.05$ & 0.50 \\
\hline
\end{tabular}

Table 4. (e).

\begin{tabular}{|c|c|c|}
\hline \multirow[b]{2}{*}{ Patient age group } & \multicolumn{2}{|c|}{ Dose coefficient in thyroid $h_{T h}\left({ }^{131} I\right)(\mu \mathrm{Gy} / \mathrm{Bq})$} \\
\hline & This method & ICRP dose coefficient \\
\hline 1 year & $6.3 \pm 0.6$ & 6.10 \\
\hline 5 years & $3.4 \pm 0.3$ & 3.30 \\
\hline 10 years & $1.5 \pm 0.1$ & 1.50 \\
\hline 15 years & $1.02 \pm 0.01$ & 1.00 \\
\hline Adult female & $0.73 \pm 0.07$ & - \\
\hline Adult male & $0.62 \pm 0.06$ & 0.64 \\
\hline
\end{tabular}

Table 4. $(f)$.

\begin{tabular}{lll}
\hline & \multicolumn{2}{l}{ Dose coefficient in thyroid $\mathbf{h}_{\mathbf{T h}}\left({ }^{131} \mathbf{I}\right)(\boldsymbol{\mu G} \mathbf{G} / \mathbf{B q})$} \\
\hline Patient age group & This method & ICRP dose coefficient \\
\hline 1 year & $7.8 \pm 0.8$ & 7.40 \\
5 years & $4.3 \pm 0.4$ & 4.10 \\
10 years & $1.8 \pm 0.2$ & 1.90 \\
15 years & $1.2 \pm 0.1$ & 1.20 \\
Adult female & $0.89 \pm 0.09$ & - \\
Adult male & $0.76 \pm 0.08$ & 0.79 \\
\hline
\end{tabular}

${ }^{131}$ I was orally administered to seven female patients of different ages presenting different hyperthyroidism pathologies as shown in Table 5. Ten days after, the thyroid ${ }^{131}$ I uptake was measured for the seven women patients by using a gamma camera type Siemens Symbia T6. An example of thyroid scintigraphy image is given in Figure 6 for patient 1 .

Service de Médecine Nucléaire - CHU Mohamed VI - Marrakech

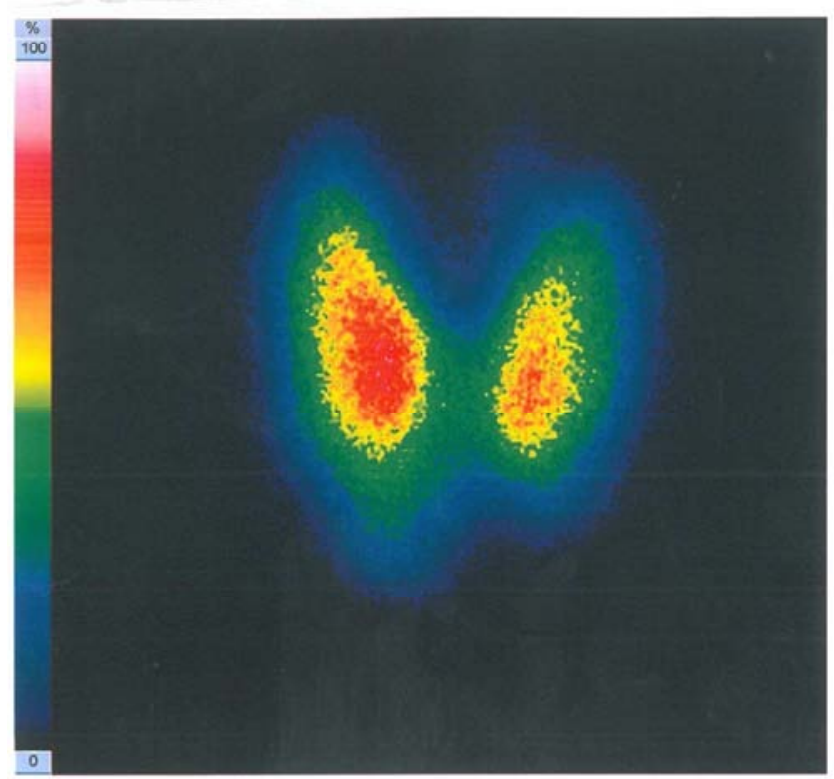

Figure 6. A thyroid image obtained for patient 1 by using a gamma camera type Siemens Symbia T6.

Committed equivalent doses to thyroid $\left(\mathrm{H}_{\mathrm{Th}}\left({ }^{131} \mathrm{I}\right)\right)$ from the ingestion of ${ }^{131} \mathrm{I}$ by the considered female patients were evaluated by using Equation (9). Data obtained are shown in Table 5. The relative uncertainty of the committed equivalent dose is estimated to be about $11 \%$.

It is to be noted from results shown in Table 5 that:

- Even though patients 2 and 5 received the same ${ }^{131} \mathrm{I}$ activity and have practically the same thyroid mass, they show different committed equivalent doses to the thyroid gland. This is because ${ }^{131}$ I uptake is larger for patient 5 than for patient 2 .

- Patient 1 shows lower committed equivalent dose to thyroid than patient 2 even if patient 1 presents higher ${ }^{131}$ I activity and ${ }^{131} \mathrm{I}$ uptake than patients 2 . This due to the fact that patient 1 has a thyroid mass larger than patient 2.

- Even though patients 2 and 6 received the same ${ }^{131} I$ activity and show practically the same ${ }^{131} \mathrm{I}$ uptake, committed equivalent dose to thyroid is clearly higher for patient 2 than for patient 6 . This is because patient 6 has a thyroid mass larger than that of patient 2 .

- Even though patients 3 and 4 have been administered different ${ }^{131}$ I activities and show different ${ }^{131}$ I uptakes and thyroid masses, they show practically identical 
committed equivalent doses to thyroid: there is compensation between the effects of these three parameters.

Committed equivalent doses to thyroid were determined for patients 4, 5 and 7 by using our model and the ICRP ingestion dose coefficients for ${ }^{131} \mathrm{I}$ corresponding to the thyroid masses of these patients [1] (Table 5). Data obtained by the two methods are in good agreement with each other.

Table 5. Data obtained for the thyroid mass, ${ }^{131}$ I administered activity $\left(A_{c}(0)\right),{ }^{131}$ I uptake and beta committed equivalent dose to thyroid $\left(H_{\text {Th }}\left({ }^{131} I\right)\right)$ from the ingestion of ${ }^{131}$ I by female patients following the treatment of hyperthyroidism diseases at the University Hospital Centre of the University of Cadi Ayyad of Marrakech (Morocco).

\begin{tabular}{|c|c|c|c|c|c|c|c|}
\hline Patient (age) & $\begin{array}{l}\text { Thyroid } \\
\text { mass (g) }\end{array}$ & Pathology & $\begin{array}{l}\mathbf{A}_{\mathrm{c}}(\mathbf{0}) \\
(\mathbf{M B q})\end{array}$ & $\begin{array}{l}{ }^{131} \text { I uptake } \\
(\%)\end{array}$ & $\begin{array}{l}\mathrm{H}_{\mathrm{Th}}\left({ }^{131} \mathrm{I}\right)(\mathrm{Sv}) \\
\text { This method }\end{array}$ & $\begin{array}{l}\text { ICRP }{ }^{131} \text { I } \\
\text { uptake (\%) }\end{array}$ & $\begin{array}{l}\mathrm{H}_{\mathrm{Th}}\left({ }^{131} \mathrm{I}\right)(\mathrm{Sv}) \\
\text { ICRP method [1] }\end{array}$ \\
\hline Patient $1(30 y)$ & 164.8 & Basedow & $476 \pm 5$ & 39.1 & $31.1 \pm 3.4$ & - & - \\
\hline Patient 2 (51y) & 57.0 & Basedow & $370 \pm 4$ & 30.4 & $54.1 \pm 5.9$ & - & - \\
\hline Patient 4 (76y) & 389.1 & Multinodular goiter & $555 \pm 5$ & 33.0 & $13.0 \pm 1.4$ & 35 & 14.26 \\
\hline Patient 5 (63y) & 55.9 & Basedow & $370 \pm 4$ & 43.2 & $78.7 \pm 8.6$ & 45 & 84.72 \\
\hline Patient6 (19y) & 208.4 & Basedow & $370 \pm 4$ & 31.4 & $15.3 \pm 1.6$ & - & - \\
\hline
\end{tabular}

\section{Conclusion}

In this study, ${ }^{131}$ I activity was calculated in different compartments of the body of different age groups of patients. It has been shown that the ${ }^{131}$ I activity is influenced by the ${ }^{131} \mathrm{I}$ uptake and transfer rate of ${ }^{131} \mathrm{I}$ between the different compartments. A new dosimetric model based on the formalism of specific beta dose deposited by $1 \mathrm{~Bq}$ of ${ }^{131} \mathrm{I}$ in the thyroid tissue was developed and validated and beta radiation doses to the thyroid from the ingestion of radioiodine $\left({ }^{131} \mathrm{I}\right)$ by patients were evaluated. It is concluded that committed equivalent doses to the thyroid gland are influenced by the ${ }^{131} \mathrm{I}$ uptake, transfer rate of ${ }^{131} \mathrm{I}$, mass of thyroid, and energy of the emitted beta minus particles. ${ }^{131} \mathrm{I}$ uptake was measured for female patients presenting different hyperthyroidism pathologies by using a gamma camera and the resulting committed equivalent doses were determined. The dosimetric model developed is a good tool for assessing beta radiation doses to the thyroid gland in order to evaluate the appropriate ${ }^{131} \mathrm{I}$ activity to be administered to patients for therapeutic and diagnostic purposes.

\section{References}

[1] International commission on Radiological Protection, Radiation dose to patients from radiopharmaceuticals, ICRP Publication 53, Ann ICRP 18 (1-4), 1987.

[2] International Commission on Radiological Protection, Nuclear decay data for dosimetric calculations, ICRP Publication 107, Ann ICRP 38 (3), 2008.

[3] P. Hall, A. Mattisson, J. D. Boice Jr, "Thyroid cancer after diagnostic administration of iodine-131". Rad. Reas., 1996, Vol. 145, pp 86-92.

[4] J. C. Sisson, J. Freitas, I. R. McDougall et al., "Radiation safety in the treatment of patients with thyroid diseases by radioiodine ${ }^{131}$ I", Practice recommendations of the American thyroid Association, Thyroid, 2011, Vol. 21, pp 335-346.
[5] A. Wiszomirska, "Iodine-131 for therapy of thyroid diseases, Physical and biological basis", Nul. Med. R., 2012, Vol. 15, pp 120-123.

[6] A. Vaiano, A. Claudio Traino, G. Boni et al., "Comparison between remnant and red-marrow absorbed dose in thyroid cancer patients submitted to ${ }^{131} \mathrm{I}$ ablative therapy after rh-TSH simulation versus hypothyroidism induced by L-thyroxine withdrawal", Nucl. Med. Commun., 2007, Vol. 28, pp 215-223.

[7] B. M. Dantas, F. F. Lima, A. L. Dantas et al., "Determination of uncertainties associated to the in vivo measurement of iodine131 in the thyroid”, Appl. Radiat. Isot., 2016, Vol. 113, pp 1-4.

[8] D. Bernard, M. D. Desruet, M. Wolf et al., "Radioiodine therapy in benign thyroid disorders. Evaluation of French nuclear medicine practices", Ann. Endocr., 2014, Vol. 75 (4), pp 241-246.

[9] I. Al-Shammeri, S. Al-Deen Mahmood, S. Al-Mohannadi et al., "Clinical experience of 2-hour I-131 thyroid uptake significance in considering the radioiodine Graves' disease treatment dose: A retrospective study", Radiogr., 2015, Vol. 21 (3), pp 254-257.

[10] T. Cappelen, J. F. Unhjem, A. L. Amundsen et al., "Radiation exposure to family members of patients with thyrotoxicosis treated with iodine-131”, Eur. J. Nucl. Med. Mol. I, 2006, Vol. 33, pp 81-86.

[11] International commission on Radiological Protection, Agedependent doses to members of the public from intakes of radionuclides: Part 1, ICRP Publication 56, Ann. ICRP 20 (2), 1989.

[12] Waterloo Maple Software, Maple Version 8.0, 2002.

[13] International commission on Radiological Protection, Recommendations of the International Commission on Radiological Protection, ICRP Publication 103, Ann ICRP 37 (2-4), 2007.

[14] M. J. Berger, J. S. Coursey, M. A. Zukcer, et al., ESTAR, PSTAR, and ASTAR, "Computer programs for calculating stopping - power and range tables for electrons, protons, and helium ions", Version 1.2.3, 2005.

[15] International commission on Radiological Protection, Basic anatomical and physiological data for use in radiological protection, ICRP Publication 89, Ann ICRP 32 (3/4), 2002. 